\title{
Movement ecology of jaguars and predator-prey interactions.
}

\author{
Carlos Cruz González ${ }^{1}$, Daniela Medellin ${ }^{1}$, Vicente Urios $^{2}$, Heliot Zarza ${ }^{3}$, and Gerardo \\ Ceballos $^{1}$ \\ ${ }^{1}$ Universidad Nacional Autonoma de Mexico \\ ${ }^{2}$ University of Alicante \\ ${ }^{3}$ Universidad Autonoma Metropolitana Unidad Lerma
}

September 25, 2021

\begin{abstract}
Jaguars (Panthera onca) are the largest felids in America, mainly threatened by habitat and prey density loss and hunting. Jaguars are mainly nocturnal predators that need large portions of suitable habitat with abundant prey populations. The aim of this work was to assess both jaguar and prey activity patterns, their relations and to understand if the presence/absence of prey and their activity patterns might determine the movements of jaguars in a spatio-temporal frame. We used data from camera trapping records of 125 jaguar events of presence from 9,360 camera trap days effort and data from five jaguars with GPS collars, to analyze: 1) Activity patterns; 2) Speed movement; 3) Traveled distances and 4) Co-occurrence for jaguars and preys. Differences between sexes and between seasons were also evaluated. A total of 12,566 segments of movement were recorded. Two activity peaks were identified between 07:00-08:00 and 22:00-23:00 hours. Average traveled distance was 265.66 $\mathrm{m} / \mathrm{h}( \pm 390.98 \mathrm{~m} / \mathrm{h})$. The maximum hourly distance was $2,760.25 \mathrm{~m} / \mathrm{h}$; with significant differences considering the hour of day $\left(\chi^{2}=324.51\right.$, df 11, p < 0.001), with higher mean values between 00:00 and 08:00 h. The average distance covered by males was higher than females $(\mathrm{Z}-24.827, \mathrm{p}<0.001): 341.64 \pm 440.03 \mathrm{~m} / \mathrm{h}$ and $146.31+-259.04 \mathrm{~m} / \mathrm{h}$ respectively. Significant differences considering seasons were found $(\mathrm{Z}=-16.442, \mathrm{p}<0.001)$ : average distance during the dry season was $230.35+-365.87 \mathrm{~m} / \mathrm{h}$ and was higher during the rainy season: $337.082+-430.45 \mathrm{~m} / \mathrm{h}$. Differences according to season were also consistent considering males and females separately (males: $\mathrm{Z}=-6.212, \mathrm{p}<0.001$; females: $\mathrm{Z}=-15.801, \mathrm{p}<0.001$ ). Occupation model analysis revealed that two of the five pairs of species (P. onca and P. tajacu and P. onca and C. paca) occur with more frequency than if they were independent, while in terms of co-detection, P. onca and P. tajacu and P. onca and C. paca showed independence
\end{abstract}

\section{Movement ecology of jaguars and predator-prey interactions.}

Carlos Cruz ${ }^{1 .} 2^{*}$, Daniela Medellín ${ }^{1}$, Vicente Urios $^{2}$, Heliot Zarza ${ }^{3}$ and Gerardo Ceballos ${ }^{1}$

${ }^{1 *}$ Laboratorio de Ecología y Conservación de Fauna Silvestre, Instituto de Ecología, Universidad Nacional Autónoma de México, Ciudad Universitaria, Coyoacán, C.P. 04510, Ciudad de México, México.

${ }^{2}$ Grupo de investigación Zoología de Vertebrados, Universidad de Alicante, Alicante, España.

${ }^{3}$ Universidad Autónoma Metropolitana, Unidad Lerma, CBS, Departamento de Ciencias Ambientales, C.P. 52005, Lerma de Villada, México, México.

*Correspondence author

E-mail:carloscga72@hotmail.com

Jaguar-prey interactions

Abstract 
1. Jaguars (Panthera onca) are the largest felids in America, a species mainly threatened by habitat loss and fragmentation, hunting, loss of prey density, and illegal trafficking. Jaguars are mainly nocturnal predators that need large portions of suitable habitat with abundant prey populations. The aim of this work was to assess both jaguar and prey activity patterns, their relations and to understand if the presence/absence of prey and their activity patterns might determine the movements of jaguars in a spatio-temporal frame.

2. Movement ecology allows us to study details of activity patterns and predator-prey dynamics. We used data from camera trapping records of 125 jaguar events of presence from 9,360 camera trap days effort and data from five jaguars with GPS collars, to analyze: 1) Temporal activity patterns; 2) Average speed movement; 3) Average of traveled distances and 4) Co-occurrence analysis for jaguars and preys. Differences between sexes and between seasons were also evaluated. A total of 12,566 segments of movement were recorded.

3. Two activity peaks were identified between 07:00-08:00 and 22:00-23:00 hours. Average traveled distance was $265.66 \mathrm{~m} / \mathrm{h}( \pm 390.98 \mathrm{~m} / \mathrm{h})$. The maximum hourly distance was $2,760.25 \mathrm{~m} / \mathrm{h}$; with significant differences considering the hour of day $\left(\chi^{2}=324.51\right.$, df $\left.11, \mathrm{p}<0.001\right)$, with higher mean values between 00:00 and 08:00 $\mathrm{h}$. The average distance covered by males was higher than females $(\mathrm{Z}-24.827, \mathrm{p}<$ 0.001): $341.64 \pm 440.03 \mathrm{~m} / \mathrm{h}$ and $146.31+-259.04 \mathrm{~m} / \mathrm{h}$ respectively. Significant differences considering seasons were found $(\mathrm{Z}=-16.442, \mathrm{p}<0.001)$ : average distance during the dry season was $230.35+-$ $365.87 \mathrm{~m} / \mathrm{h}$ and was higher during the rainy season: $337.082+-430.45 \mathrm{~m} / \mathrm{h}$. Differences according to season were also consistent considering males and females separately (males: $\mathrm{Z}=-6.212, \mathrm{p}<0.001$; females: $\mathrm{Z}=-15.801, \mathrm{p}<0.001)$. Occupation model analysis revealed that two of the five pairs of species ( $P$. onca and $P$. tajacu and $P$. onca and $C$. paca ) occur with more frequency than if they were independent, while in terms of co-detection, P. oncaand P. tajacu and P. onca and C. paca showed independence.

4. Our study provides valuable details about jaguar movement ecology and their space-time dynamics, as well as their interactions with prey species.

Key words: jaguar, movement ecology, co-occurrence, interactions, activity patterns, prey

\section{Introduction}

Loss of biodiversity is one of the most severe global environmental challenges today (Ceballos et al ., 2015; 2017). The extinction of hundreds of species and populations every year, especially vertebrates, has been well studied (Ceballos et al ., 2017), and carnivores, which include species such as bears, wolves, and wild cats, are one of the most vulnerable groups (Vie et al ., 2009).

Jaguars (Panthera onca) are the largest felid species in the Neotropics and their need for suitable habitat with abundant prey (Hunter, 2011) makes them vulnerable to the same type of human-generated threats faced by other emblematic carnivore species such as lions and tigers, namely, habitat loss and fragmentation, hunting, decrease in prey abundance, disease, and illegal trafficking (Ripple et al ., 2014; Loveridge et al ., 2016). About half of the 36 felid species are listed as threatened by the International Union for Conservation of Nature (Macdonald and Loveridge, 2010; Hunter, 2011; Durant et al ., 2017; Ghimirey and Acharya, 2017). Historical jaguar distribution range extended almost continuously from southern United States to central Argentina, and in Mexico its range currently extends along the coastal plain of the Sierra Madre Occidental and Oriental down to the Isthmus of Tehuantepec and into the Yucatan Peninsula (Ceballos, 2011).

Yucatan Peninsula supports largest jaguar population in Mexico and second in the Americas (Chavez, 2010; de la Torre et al ., 2017), it is part of the largest contiguous tropical forests in Mesoamerica which extends through Chiapas, Quintana Roo and Peten in northern Guatemala and Belize (Ceballos et al ., 2002; BricenoMendezet al ., 2017). A key component of the Mesoamerican Hotspot (Myerset al ., 2000).

An increasing number of animal movement studies, especially those involving predator-prey interactions, has highlighted the role of human activities in ecosystem endangerment (Chapman and Reyna-Hurtado, 2019). As opportunistic predators, jaguars hunt prey relative to its abundance (Rabinowitz and Nottingham, 1986; 
Aranda and Sanchez-Cordero, 1996; Garla, Setz and Gobbi, 2001), but other studies (Emmons 1987; Novack, 2003) have shown that forest jaguars exhibit species-specific prey selection. Predator-prey dynamics appear to be largely regulated by the hunting ability of the predator and avoidance strategies of the prey. While nocturnal predators like jaguars (Harmsen et al ., 2009) are usually less abundant than the species upon which they prey because of their position at the top of the trophic chain, temporal and spatial overlap among predator and prey may be as important as the relative abundance of prey in predicting encounter probabilities and defining opportunistic tendencies (Griffiths, 1975). Additionally, predators can maximize their hunting effort pay-off when prey are most vulnerable to attack (Fedriani et al ., 1999).

Assessments of predator and prey joint occupation (co-occurrence) and movements in a landscape could provide important insight into the predator-prey interactions and help explain if the spatial arrangement of a predator species and its potential prey is randomly determined or if it is driven by avoidance patterns of the prey species. In this study, we model the spatial distribution and movement of jaguars and five of their main prey species to estimate their co-occurrence in the study site.

\section{Materials and methods}

Study area

We studied jaguars in the locality of Laguna Om (18deg37'59" N, 89o05'39” W), Othon P. Blanco municipality in the south of Quintana Roo state (Fig. 1). This area is a unit of the National Protected Areas System, and located within the biological corridor between Calakmul and Sian ka'an Biosphere Reserves in the south of Yucatan Peninsula. The area is a heterogeneous mosaic dominated by cattle ranching and agricultural lands (Briceno-Mendez et al ., 2017) and three main tropical plant communities: tropical subperennial, deciduous, and seasonally flooded forests (Martinez and Galindo-Leal, 2002). The average annual temperature and rainfall are $24.6 \mathrm{oC}$ and 1,000 - 1,300 mm, respectively (INEGI, 2017). Rainwater readily percolates through the karst formations which underlay a large portion of the area (Martinez and Galindo-Leal, 2002), leaving few permanent water bodies, locally known as "aguadas" (Reyna-Hurtado et al ., 2010).

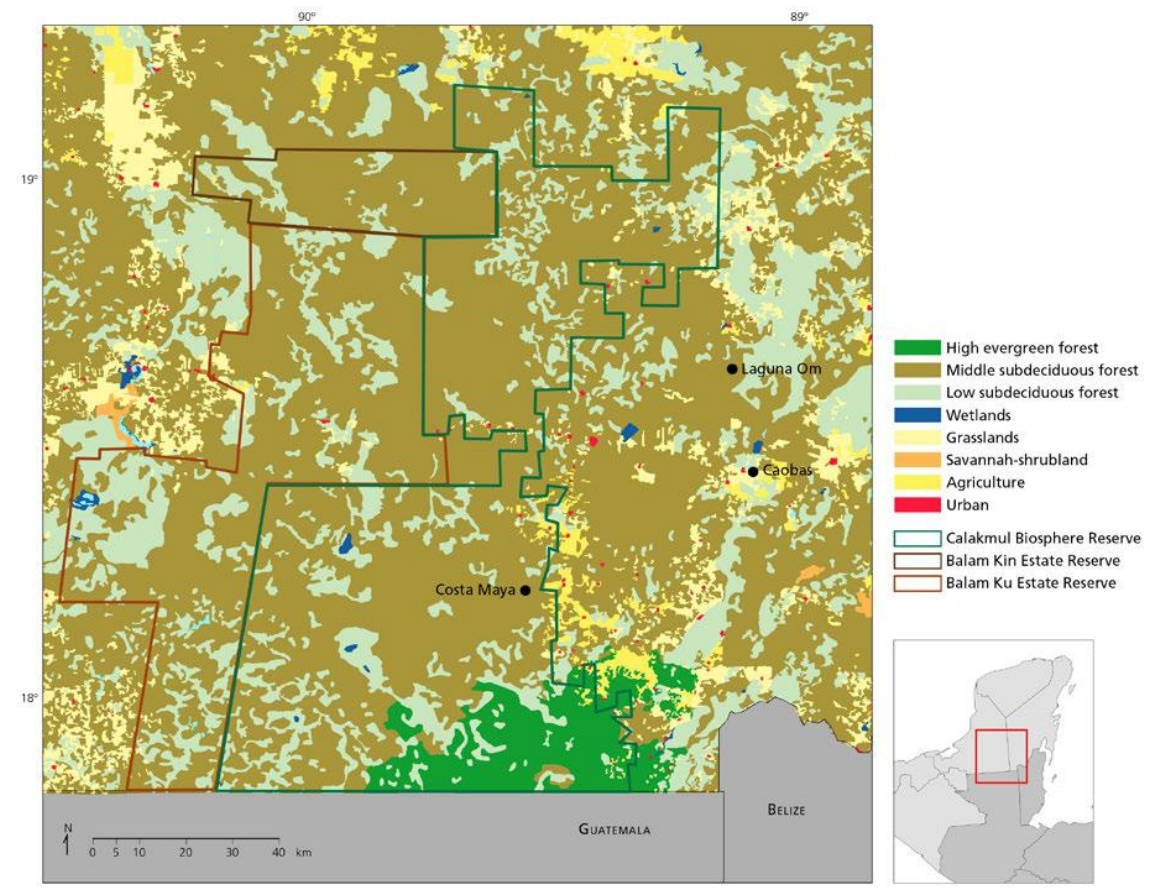

Figure 1 Study area in the southern Yucatan Peninsula 


\section{Data collection}

\section{Camera-trapping}

We analyzed 125 independent jaguar events of presence obtained from 9,360 camera trap-days recorded over a 180-day; independence was established for records at one-hour intervals. Following the guidelines of National Jaguar Census and Their Prey (CENJAGUAR) (Chávez et al ., 2007; Chávez et al ., 2016), 42 camera traps were placed throughout the $108 \mathrm{~km}^{2}$ study area partitioned into nine smaller $9 \mathrm{~km}^{2}$ grids. Each grid was equipped with three camera trap stations that included one double and two single camera traps with a separation of 1 to $1.5 \mathrm{~km}$ between stations.

\section{GPS Tracking}

Jaguars were captured used trained hounds to locate and aid in the capture of five adult jaguars between 2018 and 2019, followed the procedures employed in previous research (Crawshaw and Quigley, 1991; Hoogesteijn et al ., 1992; Morato et al ., 2001). We deployed global positioning system (GPS) radio collars (Telonics TGW47) on adult jaguars, which were programmed to record one location point every two hours and to transmit weekly; we collected a total of 16,441 location data points (from all jaguars). We obtained permission for capturing and handling jaguars from Dirección General de Vida Silvestre, Secretaria del Medio Ambiente y Recursos Naturales (SEMARNAT).

\section{Activity pattern analysis}

We analyzed the following activity patterns for jaguars in a 10- month period (August 2018 - June 2019: 1) temporal activity patterns (hours of highest activity); 2) average speed of movement (meters per hour); 3 ) average distance traveled; and 4) number of co-occurrences of jaguars and their prey.

\section{Camera-trapping data analysis}

We used the camera trap data to develop detection matrices based on the absence $(=0)$ and presence $(=$ 1) of jaguar and each of the five prey species selected. Each column on the recording sheet represented an eight-day interval during which the cameras were active, and each row represented a unique camera trap station; double stations were listed as a single station. These detection histories were used to investigate the spatial interactions between the jaguar and each of the main potential prey detected in the co-occurrence modeling. The prey species included in the analysis were Pecari tajacu, Cuniculus paca, Dasyprocta punctata , Mazama temama, and Mazama pandora. Prey species that did not present enough detections, Tayassu pecari and Dasypus novemcinctus, were excluded.

We used a single season, two-species model (MacKenzie et al ., 2004, 2006) with R-studio software and the R-presence library to estimate occupation (co-occurrence) and detection (co-detection) for each pair of species (jaguar and prey). The naive occupation, which reflects the proportion of cameras detecting a species in relation to the total number of cameras, is reported. Two population parameters, occupancy and detection, were estimated, which provide an estimate of the proportion of an area occupied by a species.

We established the jaguar as the dominant species (A) and prey (B) as the subordinate species and adopted the eight model parameters proposed by Richmond et al . (2010). For occupancy (psi or $\Psi$ ): 1) $\Psi$ A probability of occupancy for species A; 2) $\Psi$ BA - probability of occupancy for species B if species A is present; 3) $\Psi \mathrm{Ba}$ - probability of occupancy for species B if species A is absent, and for detection ( $\mathrm{r}$ or g), 4) $\mathrm{pA}$ - probability of detection for species A if species B is absent; 5) pB - probability of detection for species B if species A is absent; 6) rA probability of detection for species A if both species are present; 7) rBA - probability of detection for species B if species A was detected and both species are present; and 8) $\mathrm{rBa}$ - probability of detection for species $\mathrm{B}$ if species $\mathrm{A}$ was not detected and both species are present. If species occur independently, that is, the occupation of one species does not depend on the other, then IBA $=\Psi \mathrm{Ba}$. Similarly, detection of one species relative to the presence or absence of another can be determined; if the detection of the species occurs independently, then $\mathrm{rBA}=\mathrm{rBa}$. We also used the interaction factor (SIF) which indicates if the species of interest occur independently. The parameter nu $(\mathrm{N})$, which is the 
occupation probability estimate $(\mathrm{B} \mid \mathrm{A})$ /probability $(\mathrm{B} \mid \mathrm{a})$, indicates if the jaguar and the prey species use the sites independently, and the parameter rho $(\mathrm{P})$, which is the detection probability ( $\mathrm{rBA} /$ probability $\mathrm{rBa})$, indicates if the detection of the predator affects the detection of a prey since they both occupy a site. Nu and rho (SIF) values that equal one suggest species occur independently, but SIF values $<1$ suggest species coexist less frequently than if they were distributed independently (avoidance among the pair of species analyzed) and SIF values $>1$ suggest a tendency for species to occur more frequently than if they were distributed independently.

We used the Akaike model selection criterion (Akaike, 1973) to identify which of the three models (below) that best describes the data on the joint occurrence of each pair of species and assigned the following variable definitions: SP is the effect of the species; INT is the effect of the interaction on the presence of species $\mathrm{B}$ whether species A is present or not; INT_o is the detection level interaction when the occupation of one species changes the probability of detection of the other species; and INT_d, is the detection level interaction where the detection of one species changes the probability of detection of the other species on the same occasion of the sampling (i.e., eight-day period).

* Model 1: psi ${ }^{2} \mathrm{SP}+$ INT, p $\sim \mathrm{SP}$ + INT_o + SP:INT_o + INT_d [psi (SP P INT) p (SP P INT_o P SP T INT_o P INT_d)]. This is the most complete model with three parameters for occupancy (psi) and five parameters for detection. It assumes the probability of occupancy depends on the occupancy of A and the probability of occupancy of $\mathrm{BA}$ because $\Psi^{\mathrm{BA}}=\Psi^{\mathrm{Ba}}$. It also assumes that detection depends on $\mathrm{pA}, \mathrm{rA}, \mathrm{pB}$, $\mathrm{rBA}$ and $\mathrm{rBa}$.

* Model 2: psi $\sim$ SP, p $\sim \mathrm{SP}+$ INT_o + INT_d + SP:INT_o psi (SP) p (SP P INT_o P INT_d P SP T INT_o). Occupancy depends only on the species, and unlike model 1, assumes that species occupancy is independent. This implies $\Psi^{\mathrm{BA}}=\Psi^{\mathrm{Ba}}$ and is represented by the absence in the adjustment of the interaction term in the occupancy.

* Model 3: psi $\sim$ SP + INT, p $\sim$ SP + INT_o + SP:INT_o psi (SP P INT) p (SP P INT_o P SP T INT_o). Unlike model 1, it assumes that detection probabilities of species $\mathrm{B}$ do not depend on the detection of species A (i.e., $\mathrm{r}^{\mathrm{BA}}=\mathrm{r}^{\mathrm{Ba}}$ ).

\section{GPS tracking data analysis}

To obtain the distances traveled per hour (speed), we divided the distance traveled between two consecutive positions by the time lapse, with a maximum of two hours. We used the Kruskal-Wallis test (data failed a test for normality) to examine if there were differences relative to time of day and the Games-Howell test (Zar, 1999) to identify period of peak activity. We also used the nonparametric Mann-Whitney U-test to evaluate travel differences between sexes and the dry (December - May) and rainy (June- November) seasons. All statistical analyses were performed with IBM SPSS Statistics ver. 22.0. Significance level was set at P $<0.05$ and we present data as mean \pm standard deviation (SD).

\section{Results}

\section{Camera-trapping}

Jaguars were most active during two periods within a 24-hour cycle, 07:00-08:00 and 22:00-23:00 hours (Figure 2). The occupancy models show that two of the five pairs of species $(P$. onca $+P$. tajacuand $P$. onca + C. paca $)$ occur more frequently than they would if they were independent $\left(\Psi^{\mathrm{BA}}>\Psi^{\mathrm{Ba}}\right.$; Table 1$)$. This assessment is supported by the $n u$ parameter values of $\operatorname{SIF}<1$ (Table 2) which also indicate P. tajacu and $C$. paca show a higher occupancy in the presence of jaguars. The other three species pairing ( $P$. onca $+D$. punctata, $P$. onca $+M$. temama, and $P$. onca $+M$. pandora $)$ show an independent $\left(\Psi^{\mathrm{BA}}=\Psi^{\mathrm{Ba}}\right.$, $\mathrm{SIF}=1)$ co-occurrence but were not detected. In contrast, the co-detection of the species pairing of $P$. onca $+D$. punctata, $P$. onca $+M$. temama, and $P$. onca $+M$. pandora showed a positive interaction; these prey species and jaguars were detected more frequently than if they were independent $\left(\mathrm{r}^{\mathrm{BA}}>\mathrm{r}^{\mathrm{Ba}}\right.$; Table 2 ). This assessment is also corroborated by the rhoparameter value of SIF $>1$. Our analysis also revealed 
independence of co-detection for P. onca $+P$. tajacu and $P$. onca + C. paca $\left(\mathrm{r}^{\mathrm{BA}}=\mathrm{r}^{\mathrm{Ba}}, \mathrm{SIF}=1\right.$, Table 2$)$ and as noted in the best seven models (Table 3).

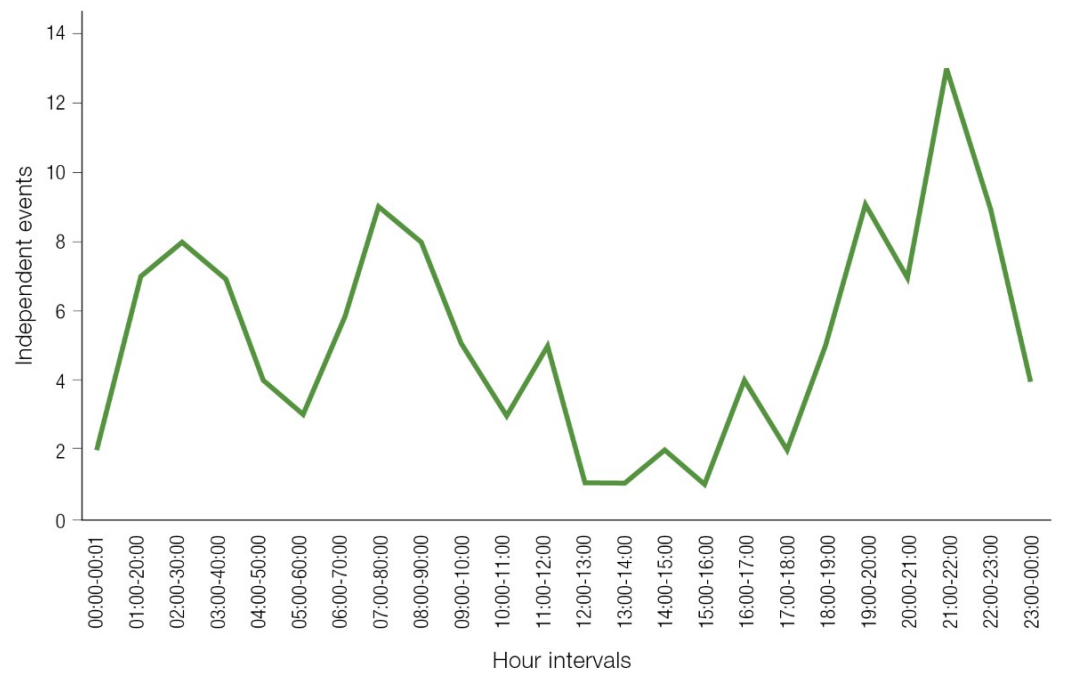

Figure 2. Hour activity patterns of 125 jaguar (Panthera onca)photographic events from camera trapping data in Laguna Om, Mexico during May-November 2018.

Table 1. Estimation of naïve occupation (occupation and detection) and occupation of both species

Pair of species

Panthera onca + Cuniculus paca

Panthera onca + Pecari tajacu

Panthera onca + Dasyprocta punctata

Panthera onca + Mazama temama

Panthera onca + Mazama pandora

\begin{tabular}{ll}
\hline Probability of naive occupancy & Naive occupancy probability (detection \\
0.925 & 0.8 \\
0.925 & 0.8 \\
0.925 & 0.75 \\
0.975 & 0.8 \\
0.875 & 0.8 \\
\hline
\end{tabular}

Table 2. Probability of co-occurrence between the jaguar and prey species.

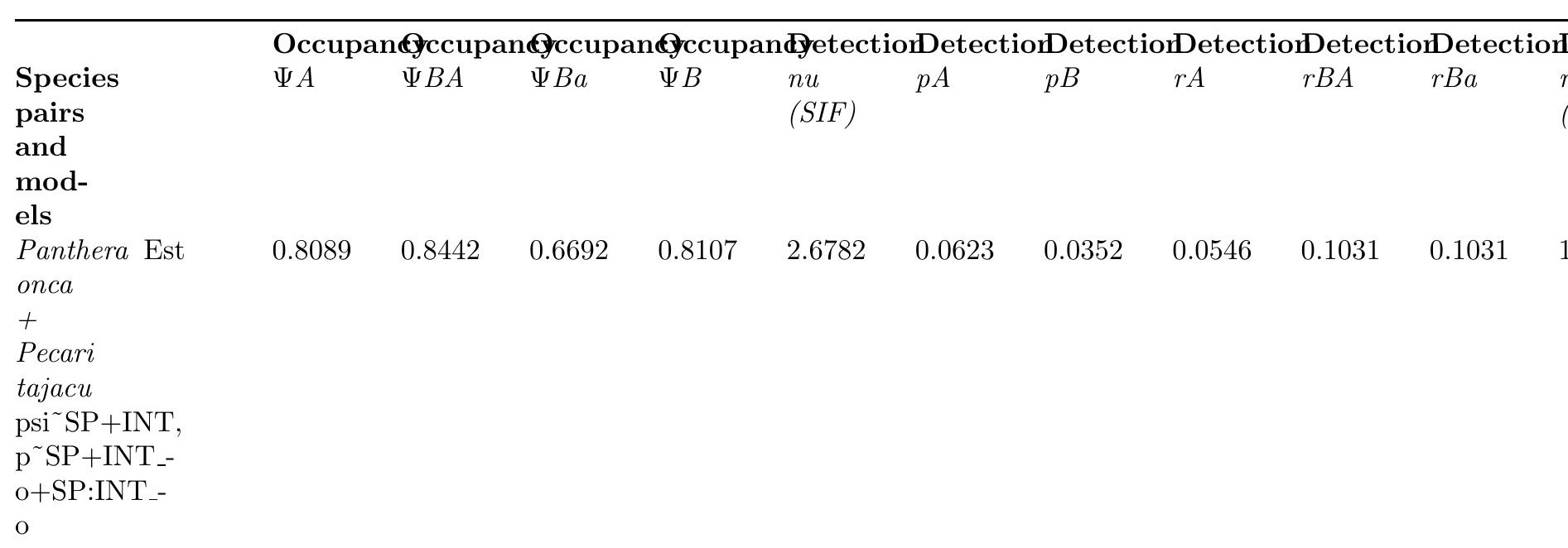




\begin{tabular}{|c|c|c|c|c|c|c|c|c|c|c|}
\hline $\mathrm{SE}$ & 0.064 & 0.0643 & 0.2001 & 0.1914 & 2.7690 & 0.0133 & 0.0121 & 0.0055 & 0.0072 & 0.0072 \\
\hline 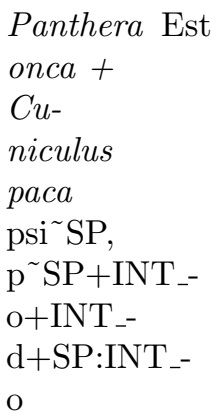 & 0.734 & 0.8313 & 0.7197 & 0.8016 & 1.9184 & 0.1034 & 0.0851 & 0.0665 & 0.0961 & 0.0961 \\
\hline 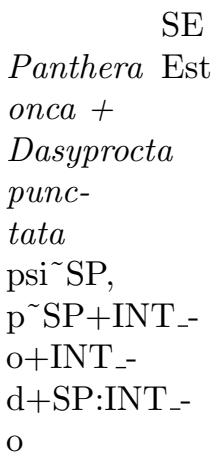 & $\begin{array}{l}0.0715 \\
0.9386\end{array}$ & $\begin{array}{l}0.0697 \\
0.9322\end{array}$ & $\begin{array}{l}0.1392 \\
0.9322\end{array}$ & $\begin{array}{l}0.1342 \\
0.9322\end{array}$ & $\begin{array}{l}1.6357 \\
1\end{array}$ & $\begin{array}{l}0.0166 \\
0\end{array}$ & $\begin{array}{l}0.0134 \\
0.0292\end{array}$ & $\begin{array}{l}0.0064 \\
0.2248\end{array}$ & $\begin{array}{l}0.0075 \\
0.1257\end{array}$ & $\begin{array}{l}0.0075 \\
0.0702\end{array}$ \\
\hline $\begin{array}{l}\quad \text { SE } \\
\text { Panthera Est } \\
\text { onca }+ \\
\text { Mazama } \\
\text { temama } \\
{\text { psi }{ }^{\sim} \mathrm{SP}} \\
\text { p }^{\sim} \mathrm{SP}+\mathrm{INT}_{-}- \\
\text {o+INT_- } \\
\text { d+SP:INT_- } \\
\text { o }\end{array}$ & $\begin{array}{l}0.0227 \\
0.8653\end{array}$ & $\begin{array}{l}0.0235 \\
0.8563\end{array}$ & $\begin{array}{l}0.0235 \\
0.8563\end{array}$ & $\begin{array}{l}0.0235 \\
0.8563\end{array}$ & $\begin{array}{l}0 \\
1\end{array}$ & $\begin{array}{l}\text { NA } \\
0.0329\end{array}$ & $\begin{array}{l}\text { NA } \\
0.0889\end{array}$ & $\begin{array}{l}0.0087 \\
0.1263\end{array}$ & $\begin{array}{l}0.0134 \\
0.1209\end{array}$ & $\begin{array}{l}0.006 \\
0.0809\end{array}$ \\
\hline 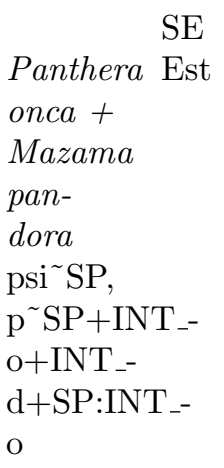 & $\begin{array}{l}0.056 \\
0.7052\end{array}$ & $\begin{array}{l}0.0571 \\
0.8308\end{array}$ & $\begin{array}{l}0.0571 \\
0.8308\end{array}$ & $\begin{array}{l}0.0571 \\
0.8308\end{array}$ & $\begin{array}{l}0 \\
1\end{array}$ & $\begin{array}{l}0.0136 \\
0.0127\end{array}$ & $\begin{array}{l}0.019 \\
0.0933\end{array}$ & $\begin{array}{l}0.0091 \\
0.0815\end{array}$ & $\begin{array}{l}0.0248 \\
0.1219\end{array}$ & $\begin{array}{l}0.008 \\
0.0841\end{array}$ \\
\hline SE & 0.0826 & 0.0606 & 0.0606 & 0.0606 & 0 & 0.0094 & 0.0146 & 0.0086 & 0.0345 & 0.009 \\
\hline
\end{tabular}

Values for all parameters are included (est, estimated parameter value; SE, standard error) for occupation probability (psi) and detection (r). The parameters for occupation and detection with the dominant species $(\mathrm{AB})$ and without the dominant species $(\mathrm{Ab})$ are highlighted, if the species occur independently then psiBA $=$ psiBa (occupation), $\mathrm{rBA}=\mathrm{rBa}$ (detection). The spatial interaction index (SIF) is reported for occupation (nu) and for detection (rho), if SIF $<1.0$ there is no co-occurrence between the examined species, and if $\mathrm{SIF}>1.0$ there is co-occurrence between the species. 
Table 3. Panthera onca and five different prey species co-occurrence occupancy models convergence; models with DAIC $>2$ are reported

\begin{tabular}{|c|c|c|c|c|}
\hline Model & AIC & DAIC & wgt & K \\
\hline $\begin{array}{l}\text { Panthera onca }+ \\
\text { Pecari tajacu } \\
\text { psi(SP P INT) p(SP } \\
\text { P INT_o P SP T } \\
\text { INT_o) } \\
\text { psi }{ }^{\sim} \text { SP+INT, } \\
\text { p } \text { SP+INT_- } \\
\text { o+SP:INT_o }\end{array}$ & 2305.1731 & 0.00 & 0.733 & 7 \\
\hline 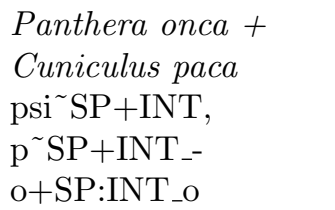 & 2422.7369 & 0.00 & 1.0000 & 7 \\
\hline $\begin{array}{l}\text { Panthera onca }+ \\
\text { Dasyprocta punctata } \\
\text { psi(SP)p(SP P } \\
\text { INT_o P INT_d P } \\
\text { SP T INT_o) }\end{array}$ & 3893.0376 & & 0.7308 & 7 \\
\hline $\begin{array}{l}\text { Panthera onca }+ \\
\text { Mazama temama } \\
\text { psi(SP)p(SP P } \\
\text { INT_o P INT_d P } \\
\text { SP T INT_o) }\end{array}$ & 2134.7755 & 0.00 & 0.54 & 7 \\
\hline $\begin{array}{l}\text { Panthera onca }+ \\
\text { Mazama temama } \\
\text { psi(SP P INT)p(SP } \\
\text { P INT_o P SP T } \\
\text { INT_o P INT_d) }\end{array}$ & 2136.106 & 1.33 & 0.28 & 8 \\
\hline $\begin{array}{l}\text { Panthera onca }+ \\
\text { Mazama pandora } \\
\text { psi(SP)p(SP P } \\
\text { INT_o P INT_d P } \\
\text { SP T INT_o) }\end{array}$ & 1678.0844 & 0.00 & 0.707 & 7 \\
\hline $\begin{array}{l}\text { Panthera onca }+ \\
\text { Mazama pandora } \\
\text { psi(SP P INT)p(SP } \\
\text { P INT_o P SP T } \\
\text { INT_o P INT_d) }\end{array}$ & 1679.905 & 1.82 & 0.285 & 8 \\
\hline
\end{tabular}

\section{GPS Tracking}

A total of 12,566 movement segments were recorded for the five jaguars tracked (mean: 2,513; SD: 1,125; Table 4). The average distance traveled by jaguars was of $265.66 \mathrm{~m} / \mathrm{h}( \pm 390.98 \mathrm{~m} / \mathrm{h})$, mean values varied depending on the individual (Table 4) between $145.33 \mathrm{~m} / \mathrm{h}$ (female, Iris) and $489.09 \mathrm{~m} / \mathrm{h}$ (male, Pedro), and the maximum hourly distance recorded was $2,760.25 \mathrm{~m} / \mathrm{h}$ (Marcos). Distances traveled differed significantly relative to the time of day $\left(\chi^{2}=324.51\right.$, df $\left.=11, p<0.001\right)$, with higher mean values recorded between 00:00 and 08:00 h (Figure 2). Although there was no prominent peak of activity, the frequency of hourly 
movements $>200 \mathrm{~m}$ was higher during the night hours and decreased during the rest of the 24-hour period, especially between 18:00 and 22:00 h (Figures 2 and 3).

Table 4. Number of segments and hourly distances traveled by each of five jaguars in the Calakmul region, Mexico

\begin{tabular}{lllll}
\hline Individual & No movement segments & Mean $(\mathbf{m} / \mathbf{h})$ & SD $(\mathbf{m} / \mathbf{h})$ & Maximum value $(\mathbf{m} / \mathbf{h})$ \\
Carlos & 1,266 & 187 & 294 & 1,616 \\
Marcos & 3,929 & 300 & 374 & 2,760 \\
Pedro & 2,419 & 489 & 547 & 2,646 \\
Iris & 3,339 & 145 & 253 & 2,041 \\
Sol & 1,613 & 148 & 269 & 1,936 \\
\hline
\end{tabular}

Considering sex of the individuals, the average distance covered by male jaguars was higher than females $(Z=-24.827, p<0.001) 341.64 \pm 440.03 \mathrm{~m} / \mathrm{h}$ and $146+-259.04 \mathrm{~m} / \mathrm{h}$, respectively. $44.5 \%$ of male jaguar movements were $>200 \mathrm{~m} / \mathrm{h}$ in contrast to only $22.3 \%$ for females, whereas $70.7 \%$ of movements by females were $<100 \mathrm{~m} / \mathrm{h}$ in contrast to only $47.7 \%$ for males (Figure 5 ). There were also significant seasonal differences in movements $(Z=-16.442, p<0.001$ ); average distance during the dry season was $230.35+-365.87 \mathrm{~m} / \mathrm{h}$ and $337.082+-430.45 \mathrm{~m} / \mathrm{h}$ during the wet season when the frequency of hourly distances higher $>500 \mathrm{~m}$ increased (Figure 5). Seasonal differences were also consistent between males $(Z=-6.212, p<0.001)$ and females $(Z=-15.801, p<0.001)$. (Figure 6 )

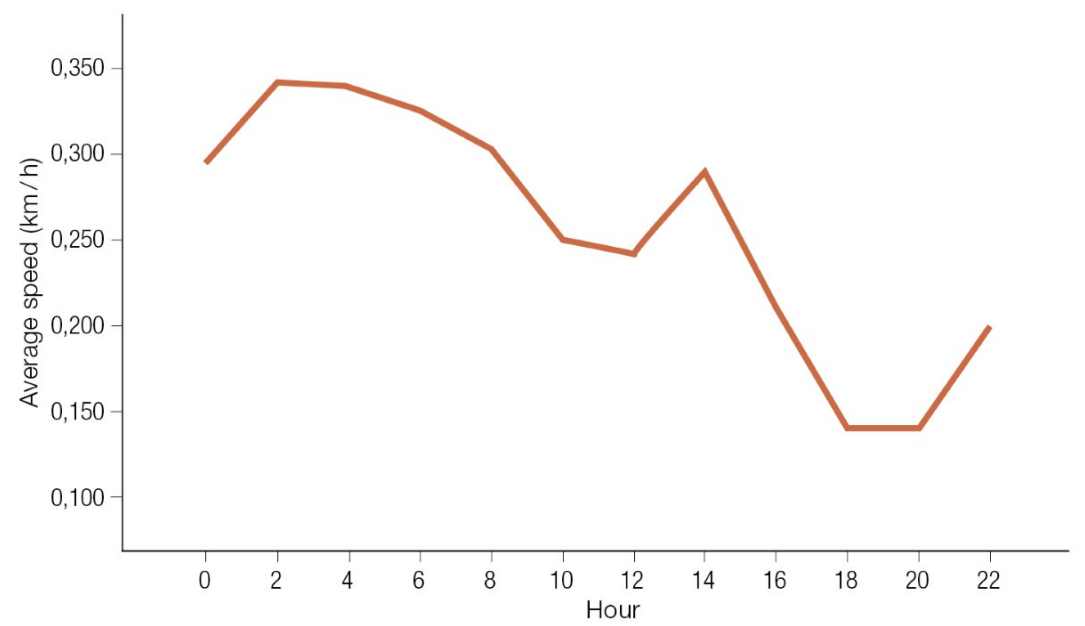

Figure 3. Average speed $(\mathrm{km} / \mathrm{h})$ of jaguars according to the hour of the day 


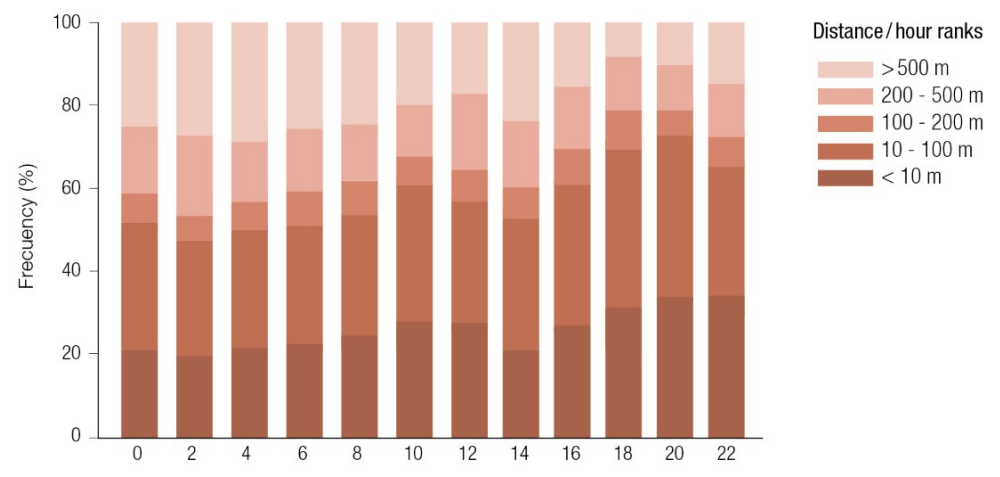

Figure 4. Frequency of jaguar movements per hour, categorized by different distance intervals according to the time of the day.

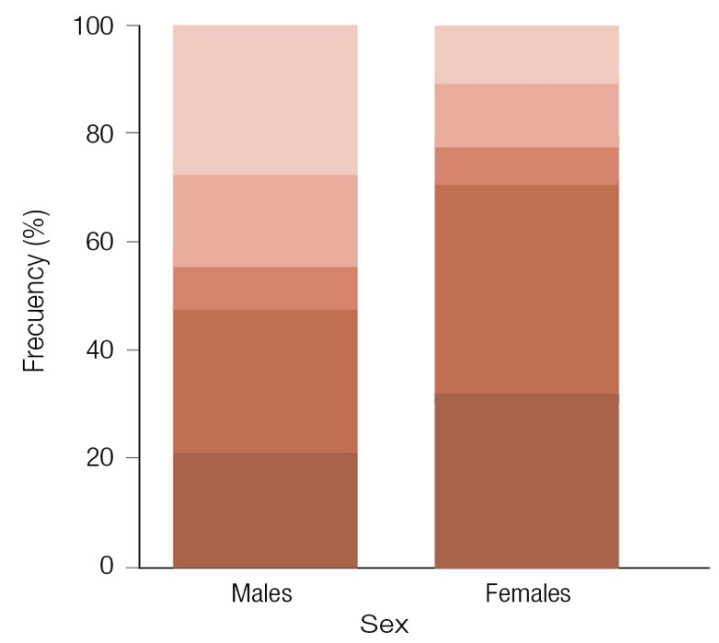

Distance/hour ranks

$>500 \mathrm{~m}$

$200-500 m$

$100-200 m$

$10-100 m$

$<10 \mathrm{~m}$

Figure 5. Frequency of hourly movements $(\mathrm{m} / \mathrm{h})$ of jaguars categorized by distance intervals and sex. 


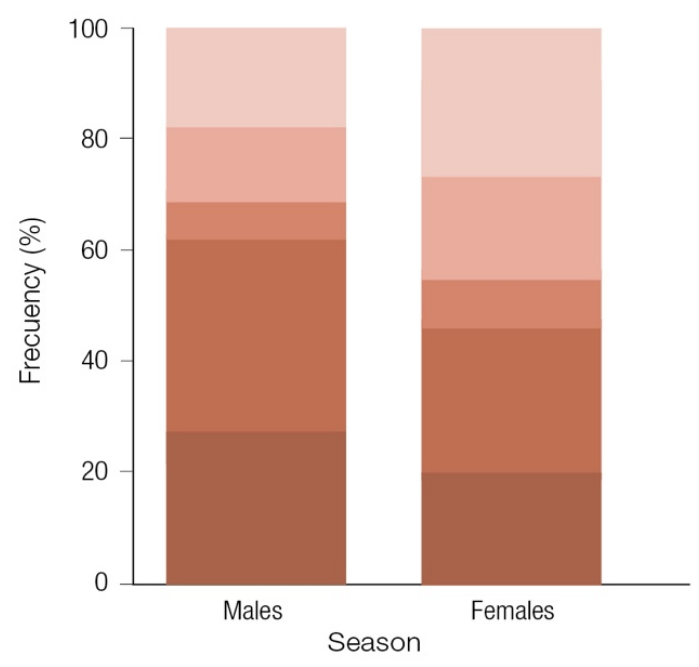

Distance/hour ranks

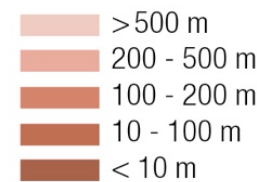

Figure 6 . Frequency of hourly movements $(\mathrm{m} / \mathrm{h})$ of jaguars categorized by distance intervals and season (dry or wet)

\section{Discussion}

Our results showed that jaguars co-occur most frequently with the collared peccary $(P$. tajacu ) and the spotted paca ( $C$. paca). While we acknowledge that co-occurrence per se does not imply interaction, our data and models reveal observations made in other studies that showed $P$. tajacu and $C$. paca were taken as prey more than $85 \%$ of the time they were present in the community (Blanchet et al ., 2020; Hayward et al ., 2016). A study of jaguar diet in Chiapas, México (Cruz et al ., 2007) revealed that the collared peccary was found in the feces three times more frequently than any other prey species. While prey diversity is very variable within the jaguar distribution range, De Oliveira (2002) observed that, excluding livestock, the mean weight of prey is $14.42+-8.63 \mathrm{~kg}$, suggesting that jaguars tend to hunt prey slightly smaller than themselves.

We hypothesize that the independent co-occurrence of jaguars with the other three prey species may be a function of abiotic factors or other environmental conditions that affect potential prey distribution, such as a negative interaction strong enough to exclude the species from capture even though it may co-occur with the jaguar (Blanchet et al ., 2020). Our sampling design may also have introduced a bias factor in the species captured. In contrast to other felids, foraging patterns of jaguars are driven by ecological and behavioral factors, like prey abundance and herd size, rather than morphological factors even though jaguars tend to avoid species outside their preferred weight range (Hayward et al ., 2016).

Although jaguars and cougars are sympatric and may share territories, they avoid being at the same place at the same time (Harsem et al ., 2009). Our study, which showed peak jaguar activity occurs at $21-22$ hours, conforms to the observations of other studies and demonstrates this time frame ensures a temporal separation from the cougar, the other top predator in the area (De la Torre et al . 2017; Hernandez et al ., 2013). Additionally, this nocturnal hunting pattern corresponds with peak activities of some prey, suggesting jaguar activity is influenced not only by interspecific competition but by the prey temporal patterns (Hernandez et al . 2013; Emmons, 1987). This pattern of peak nocturnal activity is not unlike what is observed with other sympatric felines in Mexico, the ocelot (Leopardus pardalis ) and margay (Leopardus wiedii) and with the leopard (Panthera pardus ) that exhibited peak activity that included morning and evening twilight hours (Hubelet al ., 2018). Goulard et al . (2009) reported the nocturnal activity pattern in ocelots appeared to be the same as the pattern of their main prey, and Carvajal-Villareal et al . (2012) also reported nocturnal 
activity peaks for margays their maximum distances traveled occurred between 00:00 and 8:00 hours. Our study also revealed that the between-sex differences in distance traveled for the jaguar was proportional to that observed in leopards and ocelots; males of all three species traveled twice the distance as their female counterparts (Martins and Harris, 2013; Goulart et al ., 2009). Our data also showed that the significant seasonal differences in distances jaguars traveled was not replicated by other large felids. While leopards do not show significant seasonal differences in their movement patterns, the high monthly variability in distances traveled suggests external factors such as weather condition and prey distribution and abundance influence the movement of some top predators (Hubel et al ., 2018). Likewise, the rate of movement of tigers (Panthera tigris ) does not vary significantly across seasons (Sarkar et al ., 2016), but Buderman et al . (2017) found both sexes of the Canada lynx (Lynx canadensis ) moved faster during the summer months, with males traveling at a slightly faster than females.

\section{Implications for conservation}

\section{Acknowledgements}

The authors would like to thank the Alianza WWF - Fundacion Telmex/Telcel, the Universidad Nacional Autonoma de Mexico, Amigos de Calakmul A.C., and the BBVA Foundation Award for the Conservation of Biodiversity (2017) for funding and support for this project. These financing sources had no participation in the data interpretation or in the document edition for publication. The authors also thank the Laguna Om community and local authorities for allowing us to carry out the study in their lands. The authors would also like to thank Javier Vidal-Mateo and Nubia Lara for their valuable contributions in the revision of the manuscript. This manuscript is part of the requirements of the PhD in Applied Zoology of the University of Alicante of Carlos Antonio Cruz Gonzalez.

\section{Author's contributions}

GC and CC conceived the ideas and designed methodology; CC, DM, and HZ collected the data; CC analyzed the data; CC and VU led the writing of the manuscript. All authors contributed critically to the drafts and gave final approval for publication.

\section{Data availability}

Data will be available in MoveBank.

\section{References}

Aranda, M., \& Sanchez-Cordero, V. (1996). Prey spectra of jaguar (Panthera onca) and puma (Puma concolor) in tropical forests of Mexico.Studies on Neotropical Fauna and Environment , 31 (2), 65-67.

Blanchet, F. G., Cazelles, K., \& Gravel, D. (2020). Co-occurrence is not evidence of ecological interactions. Ecology Letters 23, 1050-1063. https://doi.org/10.1111/ele.13525

Briceno-Mendez, M., Naranjo, E., Perez-Irineo, G., Contreras-Perera, Y., Sandoval-Seres, E., \& HidalgoMihart, M. G. (2017). Richness and trophic guilds of carnivorous mammals in ejido Nuevo Becal, Calakmul, Campeche, Mexico. Therya, 8 (2), 145-150.

Buderman, F. E., Hooten, M. B., Ivan, J. S., \& Shenk, T. M. (2018). Large-scale movement behavior in a reintroduced predator population.Ecography , 41(1), 126-139.

Carvajal-Villarreal, S., Caso, A., Downey, P., Moreno, A., Tewes, M. E., \& Grassman, L. I. (2012). Spatial patterns of the margay (Leopardus wiedii ; Felidae, Carnivora) at "El Cielo" Biosphere Reserve, Tamaulipas, Mexico. Mammalia, 76 (3), 237-244.

Ceballos, G., Chavez, C., Rivera, A., Manterola, C., \& Wall, B. (2002). Tamano poblacional y conservacion del jaguar en la Reserva de la Biosfera Calakmul, Campeche, Mexico. El jaguar en el nuevo milenio , 403-418. 
Ceballos, G., Ehrlich, P. R., Barnosky, A. D., Garcia, A., Pringle, R. M., \& Palmer, T. M. (2015). Accelerated modern human-induced species losses: Entering the sixth mass extinction. Science advances ,1 (5), e1400253.

Ceballos, G., Chavez, C., \& Zarza, H. (2011). El jaguar en Mexico.Mexico: Instituto de Ecologia, UNAM .

Ceballos, G., Ehrlich, P. R., \& Dirzo, R. (2017). Biological annihilation via the ongoing sixth mass extinction signaled by vertebrate population losses and declines. Proceedings of the National Academy of Science s, 114 (30), E6089-E6096.

Chapman, C. A., \& Reyna-Hurtado, R. (2019). Why Movement Ecology Matters. In Movement Ecology of Neotropical Forest Mammals (pp. 1-3). Springer, Cham.

Chavez, C., Zarza, H., de la Torre, J. A., Medellin, R. A., \& Ceballos, G. (2016). Distribucion y estado de conservacion del jaguar en Mexico.El jaguar en el siglo XXI: la perspectiva continental, 47-92. (R.A. Medellin, J.A. de la Torre, H. Zarza, C. Chavez y G. Ceballos, compiladores). Fondo de Cultura Economica, UNAM, Instituto de Ecologia. Ciudad de Mexico, Mexico.

Chavez-Tovar, J. C. (2010). Ecologia y conservacion del jaguar (Panthera onca) y puma (Puma concolor ) en la region de Calakmul y sus implicaciones para la conservacion de la Peninsula de Yucatan. Doctoral dissertation. Universidad Nacional Autonoma de Mexico. Mexico, DF .

Chavez, C., Ceballos, G., Medellin, R., \& Zarza, H. (2007).Primer censo nacional del jaguar. Conservacion y Manejo del Jaguar en Mexico estudios de caso y perspectivas. CONABIO-UNAM-Alianza WWF, Telcel. Ciudad de Mexico, Mexico, 133-141

Crawshaw Jr, P. G., \& Quigley, H. B. (1991). Jaguar spacing, activity and habitat use in a seasonally flooded environment in Brazil.Journal of Zoology , 223 (3), 357-370.

Cruz, E., Palacios, G., \& Guiris, M. (2007). Situacion actual del jaguar en Chiapas. Conservacion y manejo del jaguar en Mexico: estudios de caso y perspectivas , 81-89.

Griffiths, D. (1975). Prey availability and the food of predators.Ecology , 56 (5), 1209-1214

de la Torre, J. A., Gonzalez-Maya, J. F., Zarza, H., Ceballos, G \& Medellin, R.A. (2017). The jaguar's spots are darker than they appear: assessing the global conservation status of the jaguar Panthera onca. Oryx , $1-16$

de la Torre, J. A., Nunez, J. M., \& Medellin, R. A. (2017). Spatial requirements of jaguars and pumas in Southern Mexico. Mammalian Biology , 84 (1), 52-60.

Durant, S. M., Mitchell, N., Groom, R., Pettorelli, N., Ipavec, A., Jacobson, A. P., .. \& Young-Overton, K. (2017). The global decline of cheetah Acinonyx jubatus and what it means for conservation.Proceedings of the National Academy of Sciences , 114 (3), 528-533.

De Oliveira, T. D. (2002). Ecologia comparativa de la alimentacion del jaguar y del puma en el neotropico. El jaguar en el nuevo milenio , 265-288.

Emmons, L. H. (1987). Comparative feeding ecology of felids in a neotropical rainforest. Behavioral ecology and sociobiology ,20 (4), 271-283.

Fedriani, J. M., Palomares, F., \& Delibes, M. (1999). Niche relations among three sympatric Mediterranean carnivores. Oecologia ,121 (1), 138-148.

Ghimirey, Y., \& Acharya, R. (2018). The Vulnerable clouded leopardNeofelis nebulosa in Nepal: an update. Oryx , 52 (1), 166-170.

Goulart, F. V. B., Graipel, M. E., Tortato, M. A., Ghizoni-Jr, I. R., Oliveira-Santos, L. G. R., \& Caceres, N. C. (2009). Ecology of the ocelot (Leopardus pardalis ) in the Atlantic Forest of Southern Brazil. Neotropical Biology and Conservation , 4 (3), 137-143. 
Harmsen, B. J., Foster, R. J., Silver, S. C., Ostro, L. E., \& Doncaster, C. P. (2009). Spatial and temporal interactions of sympatric jaguars (Panthera onca) and pumas (Puma concolor) in a neotropical forest. Journal of Mammalogy, 90 (3), 612-620.

Hayward, M. W., Kamler, J. F., Montgomery, R. A., Newlove, A., Rostro-Garcia, S., Sales, L. P., \& Van Valkenburgh, B. (2016). Prey preferences of the jaguar Panthera onca reflect the post-Pleistocene demise of large prey. Frontiers in Ecology and Evolution, 3, 148.

Hernandez-SaintMartin, A. D., Rosas-Rosas, O. C., Palacio-Nunez, J., Tarango-Arambula, L. A., ClementeSanchez, F., \& Hoogesteijn, A. L. (2013). Activity patterns of jaguar, puma and their potential prey in San Luis Potosi, Mexico. Acta Zoologica Mexicana (nueva serie) ,29 (3), 520-533.

Hoogesteijn, R., Hoogesteijn, A., \& Mondolfi, E. (1992). El dilema 'depredacion vs. conservacion' del Jaguar y analisis de la mortalidad de bovinos causada por felinos en tres hatos del Llano Venezolano. InProceedings of the Symposium: Felids of Venezuela: Biology, Ecology and Conservation, Caracas, Venezuela (pp. 129-169)

Hunter, L. (2019). Carnivores of the world (Vol. 117). Princeton University Press.

Loveridge, A. J., Valeix, M., Chapron, G., Davidson, Z., Mtare, G., \& Macdonald, D. W. (2016). Conservation of large predator populations: Demographic and spatial responses of African lions to the intensity of trophy hunting. Biological Conservation, 204, 247-254.

Loveridge, A., Macdonald, D. W., \& Loveridge, A. J. (Eds.). (2010).Biology and conservation of wild felids . Oxford University Press.

MacKenzie, D. I., \& Hines, J. (2018). RPresence: R interface for program PRESENCE. $R$ package version , $2(9)$

MacKenzie, D. I., Bailey, L. L., \& Nichols, J. D. (2004). Investigating species co-occurrence patterns when species are detected imperfectly. Journal of Animal Ecology , 73 (3), 546-555.

MacKenzie, D. I., Nichols, J. D., Royle, J. A., Pollock, K. H., Bailey, L., \& Hines, J. E. (2017). Occupancy estimation and modeling: inferring patterns and dynamics of species occurrence. Elsevier.

Martinez, E., \& Galindo-Leal, C. (2002). La vegetacion de Calakmul, Campeche, Mexico: clasificacion, descripcion y distribucion.Botanical Sciences , (71), 7-32.

Martins, Q., \& Harris, S. (2013). Movement, activity and hunting behavior of leopards in the Cederberg mountains, South Africa.African Journal of Ecology , 51 (4), 571-579.

Morato, R. G., Conforti, V. A., Azevedo, F. C., Jacomo, A. T., Silveira, L., Sana, D., .. \& Barnabe, R. C. (2001). Comparative analyses of semen and endocrine characteristics of free-living versus captive jaguars (Panthera onca). Reproduction, 122 (5), 745-751.

Myers, N., Mittermeier, R. A., Mittermeier, C. G., Da Fonseca, G. A., \& Kent, J. (2000). Biodiversity hotspots for conservation priorities.Nature , 403 (6772), 853-858.

Niedballa, J., Sollmann, R., Courtiol, A., \& Wilting, A. (2016). camtrapR: an R package for efficient camera trap data management. Methods in Ecology and Evolution, 7 (12), 1457-1462.

Novack, A. J. (2003). Impacts of Subsisience Hunting on the Foraging Ecology of Jaguar and Puma in the Maya Biosphere Reserve, Guatemala (Doctoral dissertation, University of Florida).

de Oliveira, T. G. (2002). Comparative feeding ecology of jaguar and puma in the Neotropics. El jaguar en el nuevo milenio , 265-288.

Core Team, R. (2015). R: A language and environment for statistical computing. R Foundation for Statistical Computing, Vienna, Austria (2013). Supplementary Figure S , 2 . 
Rabinowitz, A. R., \& Jr, B. N. (1986). Ecology and behaviour of the jaguar (Panthers onca) in Belize, Central America. Journal of Zoology , 210 (1), 149-159.

Reyna-Hurtado, R., O’Farril, G., Sima, D., Andrade, M., Padilla, A., \& Sosa, L. (2010). Las aguadas de Calakmul, reservorios de fauna Silvestre y de la riqueza natural de Mexico. Biodiversitas , 93 , 1-6.

Garla, R. C., Setz, E. Z., \& Gobbi, N. (2001). Jaguar (Panthera onca) food habits in Atlantic Rain Forest of southeastern Brazil 1.Biotropica , 33 (4), 691-696.

Richmond, O. M., Hines, J. E., \& Beissinger, S. R. (2010). Two species occupancy models: a new parameterization applied to co-occurrence of secretive rails. Ecological Applications , 20 (7), 2036-2046.

Ripple, W. J., Estes, J. A., Beschta, R. L., Wilmers, C. C., Ritchie, E. G., Hebblewhite, M., .. \& \& Wirsing, A. J. (2014). Status and ecological effects of the world's largest carnivores. Science ,343 (6167).

Sarkar, M. S., Ramesh, K., Johnson, J. A., Sen, S., Nigam, P., Gupta, S. K., .. \& Saha, G. K. (2016). Movement and home range characteristics of reintroduced tiger (Panthera tigris ) population in Panna Tiger Reserve, central India. European Journal of Wildlife Research ,62 (5), 537-547.

Vie, J. C., Hilton-Taylor, C., \& Stuart, S. N. (Eds.). (2009). Wildlife in a changing world: an analysis of the 2008 IUCN Red List of threatened species. IUCN.

Zar, J. H. (1999). Biostatistical analysis . Pearson Education India. 